\title{
The inheritance of values in Sundanese song of Cianjuran in West Java
}

\author{
${ }^{\otimes}$ Julia, Tedi Supriyadi \\ Faculty of Education Science, Universitas Pendidikan Indonesia, Indonesia
}

Received: January 29, 2017. Revised: August 3, 2017. Accepted: December 18, 2017

\begin{abstract}
This article examines the issue of inheritance that occurs in the Sundanese Song of Cianjuran. During this time, the inheritance is dominated by the transfer of skills only, while the transfer of value tends to be ignored. Consequently, the public cannot grasp the value of what is important to Sundanese Song of Cianjuran, so that over time the Sundanese Song of Cianjuran being abandoned. Through research conducted by observation into the studio and the training venues of Sundanese Song of Cianjuran, and interviews with the artists of Sundanese Song of Cianjuran, the study results showed two things. First, the Sundanese Song of Cianjuran contains the value both in lyrics and music accompaniment, in the lyrics have meaning is quite diverse, whereas the musical accompaniment contains any value in the form of symbolic treatment. Second, the process of inheritance value, on the one hand, occurs at certain times through a casual chat after training Sundanese Song of Cianjuran finished, and on the other hand, the value of inheritance is one drawback in the regeneration of Sundanese Song of Cianjuran, because teachers tend to pass on the skills aspect alone
\end{abstract}

Keywords: inheritance value; the transmission of traditional arts; Sundanese Song of Cianjuran

How to Cite: Julia \& Supriyadi, T. (2017). The inheritance of values in Sundanese song of Cianjuran in West Java. Harmonia: Journal of Arts Research And Education, 17(2), 120-128. doi:http:/ / dx.doi.org/10.15294/harmonia.v17i2.8645

\section{INTRODUCTION}

This study attempts to study the Sundanese traditional song, Cianjuran. Cianjuran as a type of Sundanese traditional song itself can be seen and studied from various different perspectives, however, the researcher here is more focus to study the song's inheritance system of values in its society. The Sundanese song of Cianjuran is a kind of traditional art originated from West Java which is inherited from generation to generation as any other typical traditional arts from other regions. A previous research studying about local arts believe that every local art has its own characteristics that differ the art from other types of local arts from other regions (Suharto, 2016).

Sundanese Song of Cianjuran consists of two elements, vocal and pirigan. Vocal is human sound in the form of rythmical tone and pirigan is the music accompaniment. This music accompaniment it self specifically uses several music instruments, such as: kacapi indung, kacapi rincik, suling, and rebab. Furthermore, Sundanese song of Cianjuran is classified into classic Sundanese art. The 'classic' character of Sundanese song of Cianjuran can be seen from its traditional form which reflects Sundanese traditional music that exist in

\footnotetext{
${ }^{\boxplus}$ Corresponding author: Jl. Mayor Abdurachman No. 211 Sumedang Jawa Barat 45323

E-mail: juli@upi.edu
} 
the past, which is more special compared to other Sundanese sounds (Wiradiredja, 2012). The uniqueness of Sundanese song of Cianjuran also can be seen from its performance and aesthetic aspects reflected in both the song lyric and the music accompaniment (pirigan). As a traditional art which was born in royal environment, Sundanese song of Cianjuran has its own aesthetics of performance, as its way to perform in sitting position, communication in nonverbal form when the performance is being held by using musical signs, and the musical interaction between the performers and audiences which has deep appreciation from both sides. One of the senior singer of Sundanese song of Cianjuran, Rina Oesman (Ziyan, 2016), said that Sundanese Song of Cianjuran is usually performed for pasamoan (banquet/reception). It is not supposed to be performed in music concert or show which is full of audiences' or crowd's noise. This art is considerably unique. People are not allowed to talk during the song performance and are asked to deeply internalize the songs into their hearts. Therefore, when there is a mamaos or Cianjuran song show, people are not allowed to enter and leave the room freely.

Aesthetics that becomes the special identity of Sundanese song of Cianjuran, the aesthetics of song and its instruments, are represented through techniques, variations, and the ways to perform it to the audiences. According to Hermawan (2014), the song is also having some elements that become the standard in scoring the beauty (aesthetic value) from the song, one from many and become the most important is song's accessory or ornament that was shaped from dongkari chain. Elis Rosliani (Herdini, 2002) translated dongkari as song ornament which is simple and contained in every type of Sundanese sound. It means that the combination or series of dongkari-dongkari has formed a unity called ornamentation. While in its instrument, for example in kacapi indung as the main accompanist, the esthetic value is determined among others by the quality of the play (technique) and the richness of the beat pattern of kacapi indung.

Sundanese song of Cianjuran is passed down from generation to generation through traditional oral ways. Julia (2008) indicates that the art transmission in the $k a-$ capi indung instrument of Sundanese song of Cianjuran in the informal education environment is done through traditional oral method by means of pencatrikan or learning from a certain 'Guru'. While Balasubramanian (2010) research results show that the learning of Sundanese song is done through traditional oral culture, and it requires close relationship with the teacher, and active participation in various contexts and relevant activities is required.

This way, all forms of ethics and aesthetics can be protected and preserved, even showing the development as well as the change over time, since the result of inheritance is often not showed in the form of repetition or is not exactly the same as the generation that inherits it (Rochmat, 2013) . For example, the aesthetics of the song prove that after Sundanese song of Cianjuran spread out from the area of origin of Cianjur regency to Bandung, the Sundanese song of Cianjuran has increasingly showed the variants in the ornamentation of the song, as a result of the development of artists singing the Sundanese song of Cianjuran from Bandung, such as the work of the late Euis Komariah. Differences can also be found in the way kacapi indung instrument is played. Wayang panambih (extra song) which was originally performed in the rhythm of basajan (usual/ slow), now turned to be faster in the musical beat, after receiving a touch of the Sundanese pattern, which are kawih sunda and kendang Sunda through the creative hands of artists of kacapi indung Ruk -ruk Rukmana, now referred as a 'ropel' beat (Julia, 2011). In other words, all the changes and developments that occur in the Sundanese song of Cianjuran played a role in extending the age or existence of the arts.

The success of inheritance of Sundanese song of Cianjuran which is generally done through informal education, turn 
out to be more dominated on the level of inheritance alone, while the inheritance of the value contained in the Cianjuran song is still relatively forgotten. Worsen fact shows that even at this time, the skill inheritance is also decreased. It is proven by the decreasing numbers of paguron or studio of Sundanese song of Cianjuran which actively provides Sundanese song of Cianjuran training. In 2016, according to Heri Wijaya (Ziyan, 2016), the number of participants are varied from 70-80 to 100 people. These days, numbers of people signed up for learning the song is no more than 50 people. Men dominate the numbers. The chairman of Pancaniti Cianjur, D. Andri Kertanegara, delivered his dissapointment to see participants which is continued to decline in number every year. Not to mention the quality is also decreased (Heriyanto, 2016). However, better inheritance system is seen in Sumedang District. It is resulted from the role of stakeholders who willingly provide facilities and sacrificing material (money) for the sake of inheritance of Sundanese song of Cianjuran (Julia, 2016).

The decrease in quantity of enthusiast's number of Sundanese Cianjuran song could happen because Sundanese people themselves are not able to capture and understand the values contained in the art, therefore, they do not consider the importance of Sundanese song of Cianjuran. Furthermore, people have no desire to learn the art of Sundanese song of Cianjuran because they do not see values that can be applied or brought into their actual lives. While the tendency of people themselves are to learn new knowledge pr skill which is valuable, useful, and practical for their lifes both for having a good living or merely for pleasure. Raditya (Tyasrinestu, 2014) underlines this by claiming that the existence of a song should have a function and use in society; and music should be used as a medium in conveying messages of the lyrics.

Based on the above phenomenon, the researcher attempts to examine inheritance of value in Sundanese song of Cianju- ran through observation and interviews of Sundanese song of Cianjuran's artists. The assessment focuses on the following two things: 1) what values are contained in the Sundanese song of Cianjuran, and 2) how the process of inheritance value in Sundanese song of Cianjuran works. In the end, it is hoped that this study may result in a clear picture about the actual condition of the form of inheritance of value of Cianjuran Sundanese song.

\section{METHODS}

Approaches implemented in this study are karawitanologi and socio-culture. Karawitanologi is to talk about the song while social culture is to discuss the values and patterns of inheritance. The research itself was conducted in two districts in West Java, i.e. the art Pakuwon art studio in Sumedang regency, and paguron Elis Rosliani in Bandung regency. Both places were chosen since the place is quite well-known in the inheritance of Sundanese song of Cianjuran till today. Through the activity of Sundanese song of Cianjuran inheritance that is held in those two places, the researchers had dug the data about the process of the inheritance that is specifically related to the values contained in Sundanese song of Cianjuran's lyrics and musics, both through the behaviour and communication patterns that occur among teachers and students.

The data collection was done by exploring the data through direct observation. Here the researchers are involved in the study as participant which commonly seen as participation observation. In this participation, the researcher stands as one of music player, playing kacapi indung instrument in regular exercise activity. In addition, researchers also collect the data through interviews and documentation studies. Interviews were conducted by researchers by interviewing all individuals who directly involved in routine training activities. The content of the interview is related to the views of the players towards the value contained in Sundanese song of 
Cianjuran and the pattern of inheritance values that exist in the supporting community. Documentation study conducted by exploring documents in the form of recording activities and record of Sundanese song of Cianjuran and the writings related to the Sundanese song of Cianjuran texts that are exist and used.

Furthermore, the data analysis technique is done through data collection process, data reduction, data presentation, and conclusion or verification. The data obtained through the data collection process is then analyzed using qualitative research analysis techniques by Miles and Huberman (Rohidi, 2007) by data reduction, data display, and conclusions or verification. In the process of analyzing this data, the content of the song is being listed and the process of inheritance value in Sundanese song of Cianjuran that has been obtained during the study process are being interpreted and discussed using some relevant theories.

\section{RESULTS AND DISCUSSIONS}

\section{Content Value in Sundanese song of Cian-} juran

The value and meaning in the Sundanese song of Cianjuran can be seen from various perspectives (Wiradiredja et al., 2001) since value is derived from the results of educational message contained in teaching and learning (Wadiyo, 2015). In this study, the Sundanese song of Cianjuran was seen through two aspects, from the lyric's meaning and Sundanese's pirigan aspects. Specifically, the lyrical aspects are divided into two kinds, one is easily to be understood while another one is hard to be understood.

In other words, lyrics are easy to be understood when the diction used by the creator is not metaphorical or explicitly explained. It is considerably difficult to understand meaning when the words used are full of figurative meaning since the meaning is implicitly said. Due to this fact, only literary circle may serve this. For the Sundanese song of Cianjuran here, both meanings are included (Wiradiredja et al., 2001). Even, it can be said that the lyrics are mostly figurative and had hidden value. It implicitly gives the idea that the creators of the lyrics of Sundanese song of Cianjuran has quite a variety of literary skills.

According to Wiradiredja et al., (2001), the Sundanese song of Cianjuran contains certain values, such as historical, love of God, love of nature, and messages related to religious and customary education (moral, ethical, norm and law). While Wiratmadja (1996) writes that the lyrics of Sunda Cianjuran song from 404 songs based on the percentage are as follows: $k a-$ endahan alam (natural beauty) 17\%, ka-Sunda-an (Sundanesse) 6\%, pepeling (advice) 9\%, kabirahian (desire) 52\%, 3\% karumasaan (acceptance), sajarah (history) 9\%, basa Jawa (Javanesse language) 3\%, sanesna (others) $1 \%$. This number can be increased by the existence of new songs composed recenty which has not been registered yet. As written by Julia (2008), in 2008 alone, there are 700 songs which belongs to Sundanese song of Cianjuran. Most of the songs, however, contain love message or relationships between people of different gender. In other words, if the lyrics of Sunda Cianjuran wants to be used as character builder, then obviously, not all lyrics are suitable to build people characters, especially in the context of character education and culture for school-aged children.

Through the musical aspect of Sundanese song of Cianjuran, in kecapi indung, especially, the values can be expressed among others through the attitude of kacapi indung's old players. Various treatments given to kacapi indung by the music player have symbolic meanings that cannot be separated from moral values in everyday life. For example, the attitude to treat or consider kacapi indung as his own wife, they play it gently and cover it with a cloth when it is not in use. It is not merely to create the concentration of the player or to deeply engage in the play of the luminance of the indung, creating a smooth sound, or keeping the dust from the music equipment. Further, the behavior shows the con- 
cept, that:

First, 'learning the ethics through $\mathrm{ka}$ capi'. The aim of treating the kacapi politely, according to one of the interviewee, is to know how far our ability in playing the $k a-$ capi as an ethic by considering the artistic ethic. Here, the meaning reflects that the way the artist treats the music instrument may make him to get used to act politely and ethical, not only on stage but also in real life. It is believed that if an artist could treat his music instrument politely, then they he will live well and polite, too. As a small example is respecting kacapi indung during a performance, by not storing ashtrays or cigarettes over the kacapi. It can be an ethical habituation for the artist in their daily life.

Second, 'doing small things before the big things'. Treating kacapi indung politely, carefully, and keeping them clean, is not a big deal because it involves the individual relationship of an indistinguishable player with his own kacapi indung. If the attitude of caring for and maintaining the kacapi indung that in fact is easier, cannot be done by the player, then how can he do things bigger and more difficult than that? That is why, for the player, the habit of caring and maintaining kacapi indung may be a step to do other things, so this attitude can be seen as one of the representations of the ability to do bigger and more complex things in everyday life.

Third, 'from the creator to His creation'. The attitude of kacapi indung players towards the kacapi indung instrument in showing their big respect to the instrument, basically shows social and spiritual relation. In this case, respecting kacapi indung is one way to respect and glorify their God. It means that if kacapi indung players are able to give the big respect to the kecapi indung, it is expected that he also has great respect towards the man who creates that instrument, and further if kacapi indung players are able to give his high respect towards the other humans, means that he also has high respect towards the human creator, that is God. Therefore, behind the attitude of a kacapi indung player that al- ways respects kacapi indung, basically is a way to respect the God through its creation.

In Sundanese culture, this attitude is not only happened around Sundanese song of Cianjuran, the same attitude is also found in some other arts. For instance, Tarawangsa arts in Rancakalong district, Sumedang regency. Some groups, especially the old generation, treated Tarawangsa nicely, even in the beginning of learning Tarawangsa. They cannot play it carelessly, but there must be a line of ancestry, or at least family from karuhun. Therefore, some people think that Tatawangsa players are atheist since they give huge respect towards the instruments. One of the Tarawangsa players, during the interview, said that the behavior is a 'mupusti' behavior not 'migusti', that has aim to maintain those arts and not to treat the tool as the God.

Another example is the Goong Renteng music instrument treatment in Situraja district, Sumedang regency. Based on the interview during the study, it is reavealed that in Situraja, the Goong Renteng music instrument has turned into a broken instrument that cannot produce sound. It even has cracked. However, people still respect the instrument by holding a ceremony with flower and incense, bathing the instrument every once a year in Mulud month, as well as providing a special room for the instrument. In other words, the behavior of treating the instrument special can be seen as an attitude of respecting the instrument.

\section{The Inheritance of Sundanese Song of Cian- juran}

The process of inheriting culture along with the values contained in it, basically happened through three aspects, the vertical transmission, horizontal transmission, and oblique transmission (Cavalli-Sforza \& Feldman, 1981; Berry et al., 2002). The inheritance process of value in Sundanese song of Cianjuran happened through some conditions, i.e: First, when people are learning Sundanese song of Cianjuran, they would ask the teacher or 
trainer about the song. It may be related to the phenomena of behavior among the artists of Sundanese song of Cianjuran, or related to the musical and vocal aspects of Sundanese song of Cianjuran. This moment creates a communication between teacher and student, and in that moment the teacher gives advices to the students through a casual conversation after practicing the Sundanese song of Cianjuran. This activity can happen for several hours, even until late at night. The practice of Sundanese song of Cianjuran itself started after Isya or around 19.30 until midnight. The more questions delivered by the students, the longer time will be needed by the trainer to answer the questions. Therefore, one of the trainer during the interview has ever said that the inheritance value usually happened after the Sundanese song of Cianjuran. As what happened in his house, the students normally have casul conversation with him about the Cianjuran songs till 2 a.m. in the morning.

Second, inheritence process exists when the teacher observes some improperactivities or attitudes done by the students. Example of the improper attitude by students is when they sneak and look at the teacher while playing the kacapi indung. The teacher then explains the rule of playing the instrument which looking at somebody else's play is considered rude and not respectful.

Domination and implementation of Sundanese song of Cianjuran inheritance also has significance differences in every paguron of Sundanese song of Cianjuran. For example, in Pakuwon Sumedang art studio, the inheritance of the value from the teacher are not really be shown directly since it is concerned more to the inheritance of the skills (Figure 1). Meanwhile, in this case, the habituation of the ethics is being taught directly by the stakeholder or the owner of Pakuwon art studio, like, giving a rule that washing students' own dishes and the teacher's dishes is an obligation, introducing transparency in managing the show by presenting any payment proofs, allowing the students to perform everyw- here with everyone, even if the students is the member of Pakuwon art studio. It means that even if the learning process is happened informally, but it is not created feudalism atmosphere as happened in the life of the late Sundanese song of Cianjuran artists.

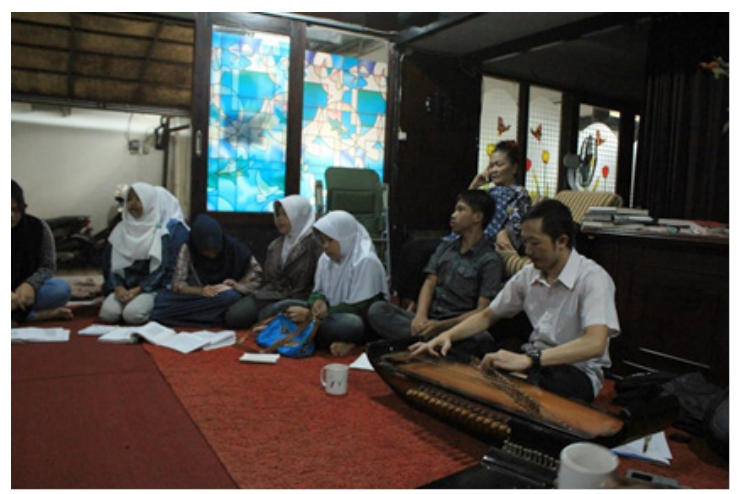

Figure 1. Learning Sundanese song of Cianjuran in Gentra Pakuwon Sumedang art studio

While the inheritance of value in Elis Rosliani's paguron, the results of the observation showed that the teachers can have a conversation that contained advices to the students, especially in the middle of break when the practice is taking place. Among the advices is to accept the differences of song variation or ornamentation among the vocalists of Sundanese song of Cianjuran. In other words, Elis Rosliani teaches the students to accept the unity in diversity, because in Sundanese song of Cianjuran world, this thing is something that can elicit conflict, or known by some singers with terms "parebut senggol" especially when pasanggiri of Sundanese song of Cianjuran is being held. This thing becomes representation of Elis Rosliani as singer that commonly invited as judge in many pasanggiri of Sundanese song or judge in competence examination of art schools. It means, as a judge that gets trust from the societies, of course this cannot be separated from the competence that she has and from her credibility as a judge who usually provide an objective assessment which based on pasanggiri rules. Those values then become part of a pasanggiri's judge of Sundanese 
song of Cianjuran, and are being inherited to the students slowly through the routine practice of Sundanese song of Cianjuran (Figure 2). Therefore, Soehardjo (2005) said that, whatever the system, process of the transmission of art is not simply by transmitting the art physically, but also by transmitting the philosophical values.

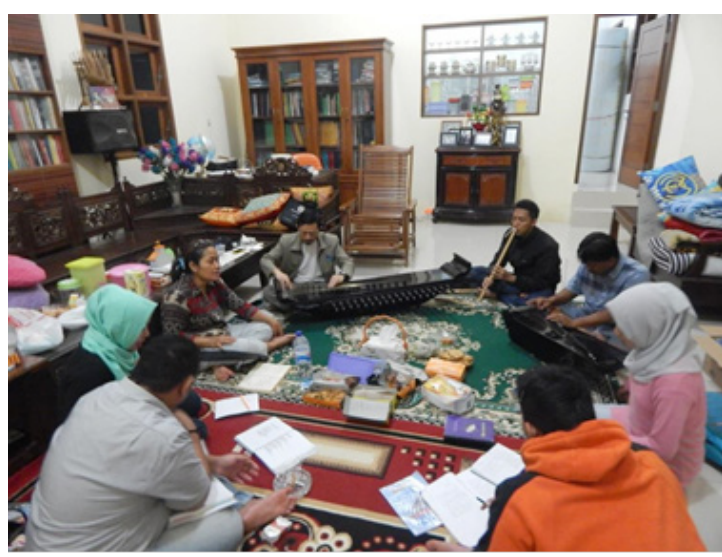

Figure 2. Learning about Sundanese song of Cianjuran in Elis Rosliani's Paguron, Bandung

Through the explanation above, in one side, it can be obtained about the description of the process of inheritance values in Sundanese song of Cianjuran which took place slowly but quite continuous. In other sides, the inheritance of values in Sundanese song of Cianjuran becomes a problem for some figures of Sundanese song of Cianjuran. For instance, one of he Cianjuran Song figure Yusuf Wiradiredja (56 year old), had ever stated that the inheritance value is one of the weaknesses in the inheritance process of Sundanese song of Cianjuran (interview on August 8, 2016). It is illustrated that started from the early age, the trainer or teacher only teaches about the song, there are no discussions to express the song, no analysis about the meaning of the lyrics, and no attempt to connect the lyric with the music. Therefore, Wiradireja as the Cianjuran song figure, decided to transmit the values contained in Sundanese song of Cianjuran by analyzing meaning of the song during the training. Through this way, Wiradireja found that not all the lyrics of Sundanese song of Cianjuran have good values or quality that can be used as an educational tool. In order to implement those things to the wider society of Sundanese song of Cianjuran, Wiradireja as one of the main committee of pasanggiri activity of Sundanese Song of Cianjuran (PTSC) Damas 2016, was trying to gathered the lyrics of song that has good quality, to be used as song lyrics that must be brought by the participants or patandang pasanggiri. The inheritance of the value through this song lyric is claimed by Wiradiredja as an easier way in teaching values in Cianjurang song because the lyrics of the song are more verbal and can be understood directly through the form of words or spoken.

Still according to Wiradireja, another important aspect in the context of inheritance of Sundanese song of Cianjuran's value is how to transfer values that is contained off the lyrics, that is from the musical aspect of Sundanese song of Cianjuran. This aspect can be validated since not all practitioner of Sundanese song of Cianjuran, especially the musical players behave in accordance with the values of Sundanese song of Cianjuran, or at least based on the characteristics of Sundanese song of Cianjuran that tends to be soft. It means that because of the soft characteristic of Sundanese song of Cianjuran, then soft character can be used as one way to build the behavior of its own practitioners to behave with touches of tenderness, decency, and etc. This condition is called by Herdini as the internalization of the values of Sundanese song of Cianjuran (Personal Communication, February 26, 2016). The internalization of value also means integrating values within a person (Fardus, 2010). It means that when there is a Sundanese song of Cianjuran's practitioner that does not behave based on the high values contained in Sundanese song of Cianjuran, then those values of Sundanese song of Cianjuran are not being internalized into the artist.

One of the strategy that can be done to realize the Sundanese song of Cianjuran's values can be internalized more generally to the wider society through formal education. Wiradireja explained that the trans- 
formation of the values should be done in school environment. Since school is the place of the young generation who will inherit the culture; and second, structural approach can be done in school environment. It means that the achievement of value learning can be measured since it is included in the area of school subject. By all means, the inheritance of Sundanese song of Cianjuran that usually happened in informal education environment which is dominated with skills inheritance, also needs to be done through formal education, at least in the local content area. As stated by Sedyawati (2007), one of the channels for inheriting cultural values in a society is through a more or less formal education system, in which there are clearly differentiated roles between teacher and student. This is in line with Hayati's point of view, who stated that school or educational institution is not only as a medium to gain the knowledge, but as a medium to develop the civilization, which has a function to pass all the potentials to the younger generation. Some of the benefits of teaching local culture and arts at school are: developing the intelligence, training the skills, creating a perfect personality, being sensitive to social life and as a cultural transmission, as well as, developing essential values as the provision of human life which is to pray to Allah. This strategy can be a way to perfect the inheritance of values through the family environment, because the family environment is the first environment for mankinds, especially the artists of Sundanese song of Cianjuran to apply the values of Sundanese song of Cianjuran.

\section{CONCLUSION}

Based on the explanation above, two points can be concluded. First, Sundanese song of Cianjuran contains varieties of values. Through the lyrics of the song, it can be identified that the meanings of song lyrics in Sundanese song of Cianjuran, includes: the historical aspect, the love of God, the love of nature, the love of fellow human beings, the messages relating to religious and customary education (moral, ethical, norm, and law), and self-reflection. Meanwhile, through pirigan, it can be identified that the value is represented through symbolic treatment from the players to the musical instrument that they are played. These values live mainly on Sundanese song of Cianjuran's in the past or old generation. Second, process of inheritance of Sundanese song of Cianjuran has been identified as two points of view that have significance differences. Through the first point of view, it can be concluded that the inheritance value of Sundanese song of Cianjuran happened in spesific times, that is in the middle of practice or after the practice, and can happen until mid-night through casual conversation. Meanwhile, through the second point of view, it can be concluded that the inheritance of value is one of the weaknesses in the inheritance system of Sundanese song of Cianjuran, since the teachers of Sundanese song of Cianjuran rarely does the inheritance teaching related to the values contained by Sundanese song of Cianjuran, since they focus more in the inheritance of the skills. Sundanese song of Cianjuran also has not been classified as a learning material in primary level. Therefore, generally, values contained in Sundanese song of Cianjuran has not been conveyed widely yet.

\section{REFERENCES}

Balasubramanian, A. (2010). Music and Regional Identity in Indonesia: Tembang Sunda of West Java. Thesis. Faculty of Emory College of Arts and Sciences of Emory University.

Berry, J. W., Poortinga, Y. H., Segall, M. H., \& Dasen, P. R. (1999). Psikologi Lintas Budaya: Riset dan Aplikasi. Jakarta: Penerbit Gramedia Pustaka Utama.

Cavalli-Sforza, L. L., \& Feldman, M. W. (1981). Cultural Transmission And Evolution: A Quantitative Approach. Princeton: Princeton University Press.

Fardus. (2010). Model Pendidikan Nilai 
Sosial Budaya dalam Keluarga dan Lingkungan Manusia Bajo di Bajoe. Jurnal Educationist, 4(1), 57-66.

Hayati. (2013). Fungsi Sekolah dan Implikasinya Bagi Pengembangan Kurikulum. Islamic Studies Journal, 1(1), 151-174.

Herdini, H. (2002). Kedudukan Lagu Papatet dalam Wanda Papantunan Tembang Sunda Cianjuran. Panggung Jurnal Seni, 29(1), 15-25.

Heriyanto, R. (2016). Tembang Sunda Cianjuran Makin Ditinggalkan (12 Oktober 2016). Pikiran Rakyat, pp. 2.

Hermawan, D. (2014). Fenomena Gender dalam Dongkari Lagu-Lagu Tembang Sunda Cianjuran. Panggung Jurnal Seni, 24(1), 25-38.

Julia. (2008). Pirigan Kacapi Indung dalam Tembang Sunda Cianjuran (Studi Komparatif terhadap Gaya RukRuk Rukmana dan Gaya Gan-Gan Garmana). Thesis. Bandung: Sekolah Pascasarjana Universitas Pendidikan Indonesia.

Julia. (2011). Gaya Petikan Kacapi Tembang Seputar Biografi Seniman Tembang Sunda. Bandung: CV. Bintang Warli Artika.

Julia, J. (2016). The Role of Stakeholder in Fostering Traditional Art Awareness (A Case Study of Sundanese Local Song 'Cianjuran' Artist Training in Sumedang Regency West Java, Indonesia). Harmonia: Journal of Arts Research And Education, 16(1), 87-94.

Rochmat, N. (2013). Pewarisan Tari Topeng Gaya Dermayon: Studi Kasus Gaya Rasinah. Resital: Jurnal Seni Pertunjukan, 14(1), 33-40.

Miles, M. B., \& Huberman, A. M. (1992).
Analisis data kualitatif: Buku sumber tentang metode-metode baru. Translation by Tjetjep Rohendi Rohidi. Jakarta: Universitas Indonesia Press.

Sedyawati, E. (2007). Budaya Indonesia: Kajian Arkeologi, Seni, dan Sejarah. Jakarta: PT. Raja Grafindo Persada.

Soehardjo, A. J. (2005). Pendidikan Seni Dari Konsep Sampai Program. Malang: Balai Kajian Seni dan Desain Universitas Negeri Malang.

Suharto, S. (2016). Banyumasan Songs as Banyumas People's Character Reflection. Harmonia Journal of Arts Research and Education, 16(1), 49-56.

Tyasrinestu, F. (2014). Lirik Musikal pada Lagu Anak Berbahasa Indonesia. Resital: Jurnal Seni Pertunjukan, 15(2), 163-168.

Wadiyo, W. (2015). Music As An Integrated Education Tool for Preschool Students. Harmonia: Journal of Arts Research and Education, 15(2), 144-151

Wiradiredja, M. Y. (2001). Tembang Sunda Cianjuran. Kerjasama Dinas P\&K Kabupaten Cianjur dan STSI Bandung.

Wiradiredja, M. Y. (2012). Peranan R. A. A. Wiranatakusumah V Dalam Penyebaran Tembang Sunda Cianjuran. Panggung Jurnal Seni, 22(3), 283-292.

Wiratmadja, A. S. (1996). Mengenal Seni Tembang Sunda. Dinas P \& K Propinsi Daerah TK. I Jawa Barat. Bandung.

Ziyan. (2016). Pasanggiri Tembang Cianjuran XXI Damas Sepi Peminat (11 Oktober 2016). Galamedia Online. 21 Oktober 2016.

Ziyan. (2016). Tembang Cianjuran Menembus Era Globalisasi Budaya (11 Oktober 2016). Galamedia Online. 21 Oktober 2016. 